\title{
Popular Culture in Libraries
}

\begin{abstract}
The study and teaching of popular culture is one of the most rapidly developing disciplines on American university campuses. Pop-culture scholars require a wide range of subliterary materials, including dime novels, comic books, phonograph recordings, and even three-dimensional objects. No single library can hope to acquire and organize for use more than a fraction of the primary sources of popular culture. Interinstitutional cooperation in identifying and preserving these fragile records of American culture is underway, but many unsolved problems remain for librarians and scholars.
\end{abstract}

A

MONG THE NEWLY-EMERGING DISCIPLINES, intended to broaden the base of higher education in America and to equalize opportunities, is the study of the literature, art and music produced for mass consumption. The proponents of this new discipline reject the idea that a nation's culture must necessarily be aristocratic and elitist, representing the tastes of a minority. Popularity, they point out to traditionalist "high culture" critics, does not inevitably equate with cheap, bad, or meretricious. Boasting its own method, equal to that of the older, established disciplines, popular culture objectively treats the attitudes and values of the widest cross section of our society. It also aims to prepare students and teachers to understand and to cope with the problems of a modern technocracy. At a recent convention of the popular Culture Association held at Toledo, Ohio, some 1,000 educators from the United States and Canada gathered to hear papers on such varied topics as "Playboy and Politics," "Female Stereotypes in Popular Literature," and "The Super Bowl Society."

Popular culture has been defined "as

Mr. Clarke is professor, University of Wisconsin Library School, Madison. that part of culture abstracted from the total body of intellectual and imaginative work which each generation receives, which is not narrowly elitist or aimed at special audiences, and which is generally (but not necessarily) disseminated via the mass media." 2 It includes the three subdivisions of popular, mass, and folk culture. Other popculture scholars would add to this definition the "myriad productions" of our contemporary counterculture. Closely related to this new academic specialization, are those aspects of social history concerned with the mind and behavior of the poorer or working classes. To study the attitudes of these nonelites, a social historian of Latin America noted recently, it is necessary to neglect public pronouncements and focus instead "on expressions of mass culture: popular songs, cheap novels, and oral traditions." 3 Even the exclusive fraternity of intellectual historians has begun to widen its elite field from their traditional concern with "high culture" to study the influence of popular literature on the development of a class consciousness.

The sheer mass and variety of these publications is so vast that it is beyond the physical capacity of even the largest 
library to acquire more than a fraction of the total output. The primary sources of popular culture include pulp magazines, dime novels, comic strips (over 10,000 strips have been published in the United States alone since James Swinnerton's "Little Bears" first appeared in the San Francisco Examiner in 1893), sheet music, phonograph records and magnetic tapes, films, old Sears Roebuck catalogs, and even three-dimensional artifacts. Matchbook covers and greeting cards find a place on some library shelves alongside Little Orphan Annie decoder pins. The subjects covered in these materials range from athletics, advertising, and feminism, to burlesque, and Captain Marvel.

Fortunately, a number of major research libraries have assumed a national responsibility to preserve some of these fragile documents of American cultural history. In the large public universities the development of these collections has usually been inspired by the demands of scholars; in some endowed institutions, however, such as the Newberry and the New York Public Library a few farsighted librarians began collecting popular literature on their own initiative decades ago. The Library of Congress possesses rich treasures of films, music, and the theatre, acquired almost incidentally, it appears, through copyright deposits. The Center for Research Libraries in Chicago has assembled a representative selection of popular magazines and comics published since 1950, most of which sell a million or more copies each issue on the newsstands. This collection was formed by purchasing a sampling of current issues at semiannual intervals from the largest wholesale distributor in Chicago. The titles are not cataloged individually but are organized by broad subjects such as Crime and Detective, Romance and Confessions, Girlies and Comics.

Other scholarly institutions have concentrated on special aspects of popular culture. Thus, the Wisconsin State Historical Society maintains a national archive of circus materials including programs, posters, costumes, and trade papers in its Circus World Museum at Baraboo. Its Mass Communications History Center at Madison boasts an indepth collection of some of the nation's "significant historical records from all phases of the mass media: radio, television, the press, advertising, public relations, theatre and cinema." These include original radio and television scripts (Fibber McGee and Molly, and the Great Gildersleeve for example), news dispatches, political cartoons, discs, and many United Artists' films on permanent deposit. Since these materials have been deposited in various libraries around the country, it is apparent that some sort of finding list (perhaps modeled on the National Union Catalog) is needed to locate old TV and radio scripts for researchers.

Since a university community inevitably represents a wide spectrum of interests and approaches to scholarship, many academic libraries have already acquired a limited range of popular culture for instruction or research. Typically, the George H. Hess collection at the University of Minnesota contains a representative selection of dime novels featuring the incredible exploits of Buffalo Bill, Deadwood Dick, and Nick Carter, "the world's greatest detective." The Pulitzer prize-winning historian Merle Curti has called dime novels "the nearest thing we have in this country to a - true proletarian literature, that is, a literature written for the great mass of people and actually read by them."4 Written according to a formula and cheaply produced, dime novels, pulp magazines, and story papers constitute an essential record of the gradual democratization of American culture. Although the Hess collection is well known to scholars, similar materials in other academic libraries often remain 
locked in the obscurity of the rare-book room. Clearly, a guide to the resources in popular culture held by American libraries is needed soon if we are to avoid unnecessary duplication and undue frustration by our unsatisfied patrons.

In many colleges and universities the curriculum has long included courses that make heavy use of materials that "once catered to the tastes of a relatively uneducated public." It is estimated that over 500 schools now offer courses on popular culture, often under such strange rubrics as the History of the Westward Movement, Urban Studies, Humanities, or even Freshman English. Quite recently, a substantial number of courses boldly titled Popular Culture have been established, occasionally leading to a joint major or a minor in American studies or folklore. For their class assignments undergraduates in these courses are often required to delve into dime novels and comic books; graduate students may be expected to write theses on films or radio scripts. The schools offering separate courses in popular culture range in size from small liberal arts colleges to such academic giants as Michigan State University, the University of California at Los Angeles, and the University of Chicago.

The State University at Bowling Green in Ohio is generally recognized as a focal point for the serious study of popular culture. An interdisciplinary program of nearly two dozen courses leads to an undergraduate major and even to a master's degree in this discipline. Its primary goal is "not only to take new and fresh approaches to subjects ordinarily studied but also to bring in new materials" in order to produce competent and original researchers in popular culture. ${ }^{5}$ Emphasis is on the scholarly interpretation of what a society reads and writes so that we can better understand the taste of the mass of the people and what influences it.
The Center for the Study of Popular Culture at Bowling Green maintains a large library-museum whose holdings range from science fiction, comic books, and pulp magazines to phonograph records and artifacts. Any publication or object that reflects the phenomenon of plebian taste is zealously collected there, no matter how unconventional it might seem to traditional researchers. Their long-range aim is to build the finest such collection in America, and to make it readily accessible to students and scholars from all over the world.

An important source of information on this emerging discipline is the Journal of Popular Culture, now in its fifth year. This is an official publication of the Popular Culture Association, the Popular Literature Section of the Modern Language Association, and the Popular Culture Section of the Midwest MLA. In it can be found book reviews, interviews with popular artists and composers, notes on films, and long critical articles on "popular culture in the broadest sense of that term." An examination of this journal reveals a wide variety of learned essays on religion, architecture, the cowboy as hero, and the American Chautauqua movement. Ironically, its authors' approach sometimes closely resembles "elitist" literary criticism with laudatory references to Paul Tillich and condescending remarks about Rod McKuen. Other journals are devoted to the serious study of special aspects of popular culture, such as the graphic arts (The Graphic Story Magazine) or local customs and traditions (The Journal of American Folklore).

Popular culture is a complex subject, almost limitless in scope, and it requires considerable skill, knowledge, and money on the part of librarians and libraries to cover it adequately. In these days of tight budgets and rising costs, librarians are expected to develop rational policies for keeping the nature and rate of collection growth within the cost 
bounds set by the university. ${ }^{6}$ Collecting in excess of campus needs has come under close scrutiny, particularly the collecting of publications that appear to have marginal utility. Since no single library (public or private) appears able or willing to collect and make accessible more than a fraction of the total output of popular culture, interinstitutional cooperation in acquisitions seems to offer the greatest benefits for scholars working these vineyards. To organize these subliterary materials raises other problems for librarians who must often devise alternatives to cataloging and classification. For some collections in traditional formats the solution is relatively simple. Thus, the O'Brien collection of 1931 dime novels at the Huntington Library is classified by type and the locality of the plot rather than by author or genre. Seventeen broad headings ranging from City Life and The Sea to Indian Tales and Fur Trapping were identified by these easily discernible characteristics. ${ }^{7}$ At Bowling Green's Popular Culture Center a 15,000 item collection of matchbooks, most of which advertise something or other, has been catalogued into areas such as "beverages, recreation, automobiles, and even caskets." 8 Understandably, these flammable materials must be specially processed by the curators in order to avoid combustion. As new categories of ephemera in varying shapes and sizes arise, librarians will have to devise new sets of rules and organizational procedures to cope with the problems they may present.

The preservation of these fragile and often deteriorating materials raises still another major problem. If their physical deterioration isn't quickly stabilized, many of these publications, recordings, and cheap artifacts will no longer be usable for research. Microfilming the printed matter offers a partial solution but simple economics requires that some criteria be established to decide what will be preserved and what discarded. This process of selection and evaluation is time-consuming and expensive. Some librarians argue that it is cheaper to film everything, keeping the bad with the good, since no one knows what will prove the most valuable for future study and research. Problems such as the ones outlined in this paper call for frequent consultation between pop-culture scholars and their librarians. The best hope for the future of this new discipline seems to lie in the fact that a meaningful dialogue has already begun on many campuses across the country.

\section{REFERENCES}

1. The Toledo Blade (6 and 7 April 1972).

2. This definition is taken from an interview with Professor Arthur Browne, a distinguished scholar in this field, as reported by Barb Brucker, "Popular Culture Study: The Wave of Tomorrow," The BG News (18 Jan. 1972).

3. Peter Smith, Prospects for Quantitative Research on Latin American History (mimeographed report, 1971) p. 22-23.

4. Merle Curti, "Dime Novels and the American Tradition," Yale Review 26:761 (June 1937).
5. A Proposal for a Master of Arts in Popular Culture, Bowling Green State University (Bowling Green, Ohio, 15 Feb. 1971) 32 p.

6. Stephen A. McCarthy, "The Role of National and Academic Libraries in Scientific Progress and in Education," Libri 21:287-97 (1971).

7. Philip Durham, "A General Classification of 1,531 Dime Novels," Huntington Library Quarterly 17:287-91 (May 1954).

8. The BG News (5 May 1972). 